\title{
Ewing sarcoma of proximal tibial epiphysis: An unusual presentation with review of literature
}

\author{
Ruchi Sinha ${ }^{1}$, Iffat Jamal2,", Amar Kumar ${ }^{3}$, Anup Kumar ${ }^{4}$ \\ ${ }^{1,4}$ Addtional Professor, ${ }^{2}$ Senior Resident, ${ }^{3}$ Tutor, ${ }^{1-3}$ Dept. of Pathology/Lab Medicine, ${ }^{4}$ Dept. of Orthopaedics, All India Institute \\ of Medical Sciences, (AIIMS) Patna, Bihar, India
}

*Corresponding Author:

Email: iffatjamal111@gmail.com

Received: $17^{\text {th }}$ July, 2017

Accepted: $11^{\text {th }}$ November, 2017

\begin{abstract}
Ewing's sarcoma/Primitive neuroectodermal tumor (ES/PNET) of bone is a rare childhood tumor most commonly located in the metadiaphysis. It is more commonly seen in the appendicular skeleton and typically involves femur, tibia, humerus or fibula. Within the long bones, the tumor is always metaphyseal or diaphyseal (mid-diaphysis: 33\%, metadiaphysis: $44 \%$, metaphyseal: $15 \%$ ). Rarely $1 \%-2 \%$ of ES may involve epiphysis. In skeletally immature patients, lesions of the epiphysis are rarely malignant, with the most common diagnosis benign chondroblastoma. We report a case of ES of the tibial epiphysis in a 16 year old boy presenting with complaints of pain around right knee joint for six months associated with fever and restricted mobility of knee joint. Magnetic resonance imaging (MRI) of the patient's right knee revealed a large lesion in the centre of upper tibial epiphysis showing hypointense signal on T1 \& T2W1 extending from the articular surface through the epiphyseal plate into the upper metaphyseal region. MRI findings suggested an infective pathology with differential diagnosis of Brodie's abscess and chondroblastoma. Based on the imaging characteristics, the patient's age and the lesion's location a preliminary diagnosis of chondroblastoma was made. Debridement and curettage of the lesion was performed and sent for histopathological examination. Microscopy and subsequent immunohistochemistry confirmed it to be a case of ES. An extensive research of literature was done and very few reports Of ES at epiphyseal location were found which make our case worth reporting. This case highlights the rarity of epiphyseally located Ewing sarcoma cases and thus suggesting that the diagnosis of ES should also be considered for pediatric epiphyseal tumors.
\end{abstract}

Keywords: Ewing tumor, Primitive neuroectodermal tumor, Metadiaphysis, Epiphysis, Metaphyseal, Chondroblastoma.

\section{Introduction}

Ewing sarcoma is the second most common primary malignant bone tumour of childhood and adolescence following osteosarcoma. ${ }^{1}$ Diaphysis of the long bones (femur, tibia and humerus), flat bones like ribs, scapula and pelvis are the preferred sites of ES. ${ }^{2}$ Involvement of proximal metaphysis of tibia is rare with a reported incidence of 4-11\%. Rarely $1 \%-2 \%$ of ES may involve epiphysis. ${ }^{4}$ Clinically ES may present as a localized, painful mass or with systemic symptoms such as fever, malaise, weight loss, leucocytosis and increased erythrocyte sedimentation rate. ${ }^{5}$ Radiologically, the most common finding in ES is a lytic lesion but there may be regions of increased density due to stimulation of new bone formation. As the tumor invades through the cortex, it often elevates the periosteum gradually. This elevation produces the characteristic multiple layers of subperiosteal reactive new bone, which produces the onionskin appearance. ${ }^{6}$

The differential diagnosis of epiphyseal bone lesions in children include infections, enchondroma, chondroblastoma, giant cell tumor, clear cell chondrosarcoma and langerhans cell histiocytosis. ${ }^{7}$ Malignant lesions of epiphysis are rare. A large series of 2758 tumor cases from a German tumor registry in 1996 found no cases of primary malignant bone tumor of the epiphysis and fewer than 10 cases of primary osteosarcoma of the epiphysis. No case of ES was found. ${ }^{7,8}$

This article presents a case of primary ES/PNET of the proximal tibial epiphysis in a 16 year old boy. Epiphyseal location of Ewing's tumour is a very rare occurrence and only $1 \%$ to $2 \%$ of cases have been reported so far in English literature which makes our case worth reporting.

\section{Case Report}

A 16 year old boy presented with pain around knee joint for 6 months with restricted mobility of the joint and associated persisting low grade fever. Magnetic resonance imaging (MRI) showed a large, $4.6 \times 1.9 \mathrm{~cm}$ lesion in the centre of tibial epiphysis showing hypointense signal on T1 \& T2W1, extending from the articular surface through the epiphyseal plate into the upper metaphyseal region. (Fig. 1) MRI findings was reported as an infective pathology like Brodie's abscess with a differential diagnosis of chondroblastoma. Based on the imaging characteristics, the patient's age, and the lesion's location, a presumptive clinical diagnosis of chondroblastoma was made. Debridement and curettage was done and the tissue was sent for histopathology. Grossly, multiple dark brown soft tissue bits admixed with bony fragments altogether measuring $3.5 \times 2.5 \times 1.5$ $\mathrm{cm}$ were received. Microscopy revealed presence of 
diffuse sheets of small, uniform, round to oval uniform cells with round nuclei, inconspicuous nucleoli and fine chromatin. The cytoplasmic boundaries of the cells were indistinct and appeared to form syncytium with intervening fibrin deposits. The tumour cells were seen permeating the marrow spaces with angiocentric growth pattern. Mitotic activity was low and atypical mitosis were not seen. Necrosis was focal and scanty. (Fig. 2) A histopathological diagnosis of ES was made which was confirmed by immunohistochemistry (IHC). IHC revealed a diffuse membranous positivity for CD99 or MIC-2, diffuse positive nuclear staining for FLI-1 and negative staining with CD10 and leucocyte common antigen (LCA) which confirmed it to be a case of Ewing's sarcoma originating from right tibial epiphysis. (Fig. 3-6)

Following the histopathological diagnosis, Positron emission tomography-computed tomography scan (PET-CT) was performed which revealed an osteolytic lesion in right tibial epiphysis with post curettage changes in the surrounding soft tissue with no FDG avid lesion at any other site in the scan.

The patient underwent curettage and bone grafting. He received five cycles of adjuvant chemotherapy and currently undergoing radiotherapy. After 6 months of follow up he is doing fine.

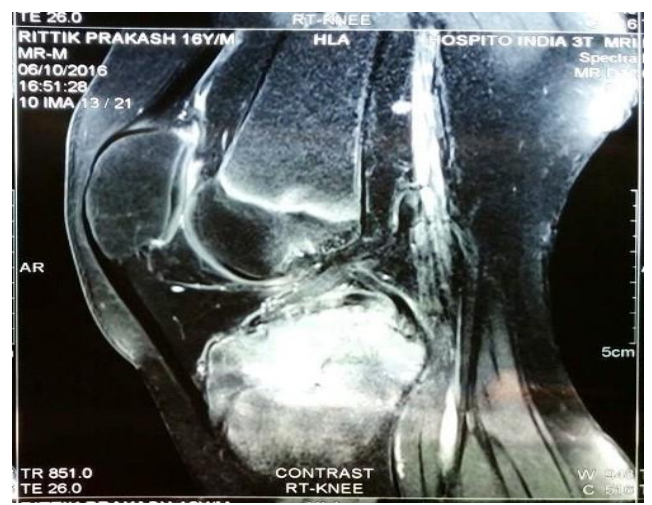

Fig. 1: MRI showing a large hypointense lesion in the centre of tibial epiphysis extending from the articular surface through the epiphyseal plate into the upper metaphyseal region

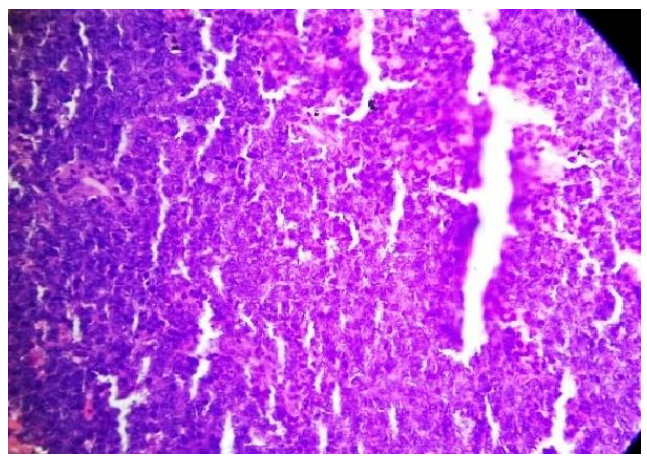

Fig. 2: Microphotograph showing presence of diffuse sheets of small, uniform, round to oval blue tumor cells with round nuclei, inconspicuous nucleoli and fine chromatin with indistinct cytoplasmic boundaries. (H\& E;400X)

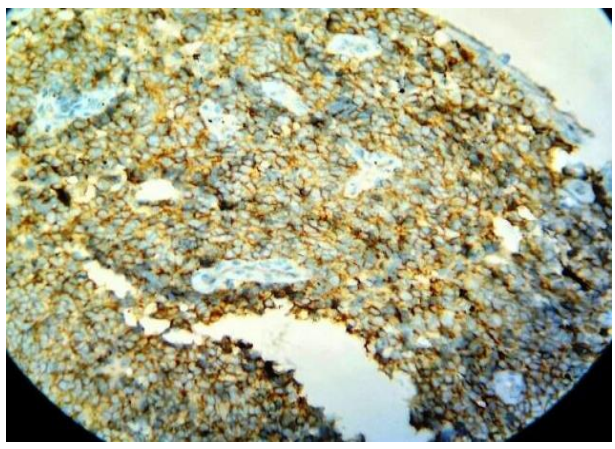

Fig. 3: IHC microphotograph showing a diffuse membranous positivity for CD99 or MIC-2. (DAB;400X)

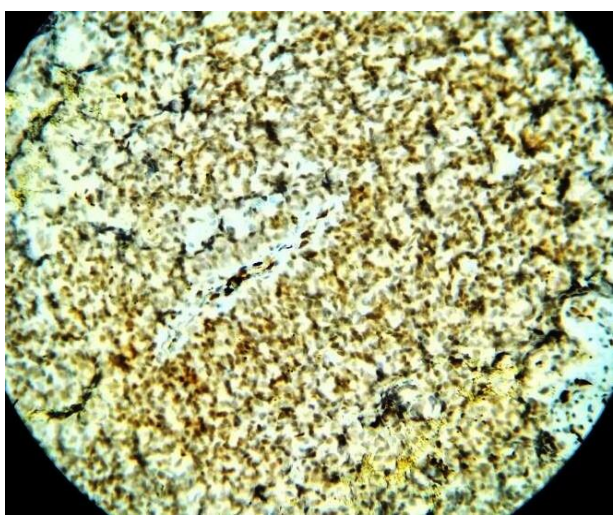

Fig.4: IHC microphotograph showing diffuse positive nuclear staining for FLI-1 .(DAB;400X)

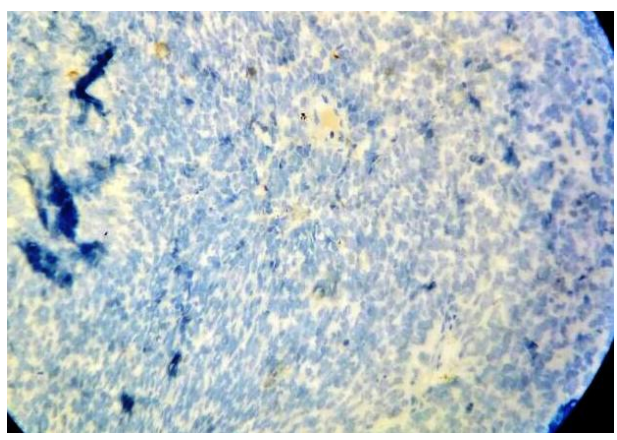

Fig. 5: IHC microphotograph showing negative staining with CD10. (DAB;400X) 


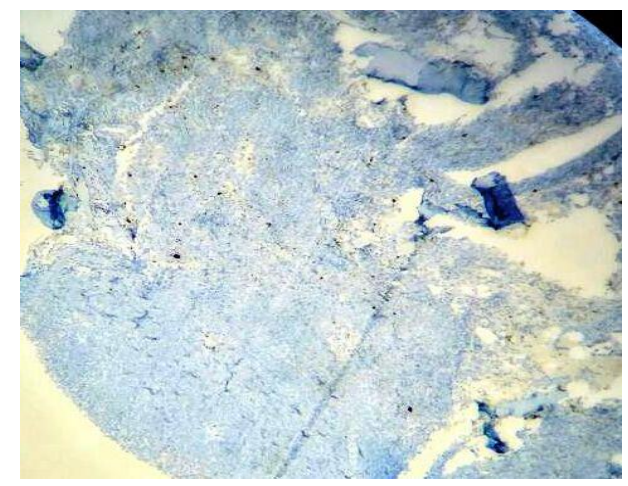

Fig. 6: IHC microphotograph showing negative staining with Leucocyte common antigen (LCA). (DAB;400)

\section{Discussion}

ES accounts for approximately $3 \%$ of all malignant childhood tumours and $10 \%$ of primary bone malignancies. ${ }^{9}$ It is most common in second decade of life. Patients present with swelling and a mass especially when the tumour is located in the extremity. ${ }^{8,9}$ ES can involve any bone with approximately $50 \%$ of cases involving long bones and $30 \%$ occurring in pelvis. As for location within long bones, the tumor is almost always metaphyseal or diaphyseal (mid-diaphysis: 33\%, metadiaphysis: $44 \%$, metaphyseal: $15 \%)^{10}$
In 1984, the Intergroup Ewing's Sarcoma Study, identified 206 patients with skeletal ES in a study on 7299 cases; of these approximately $57 \%$ were located in the metadiaphysis and $35 \%$ presented in diaphysis and only one patient $(0.5 \%)$ presented with lesion in the epiphysis. ${ }^{11}$

Minimal discussion of cases of primary epiphyseal ES/PNET are found in the literature. Panuel et al., in 1993 reported a case series of five patients with ES/PNET and found that one patient that had transphyseal spread of the disease with involvement of the epiphysis. However this was a case of primary ES in the distal femoral metaphysis that then spread distally into epiphysis. ${ }^{12}$

In 2003, Moscolo et al. reported a case of epiphyseal ES of the proximal tibial epiphysis who presented with knee pain. ${ }^{13}$ Another report by Kowalezyk et al. was published regarding PNET of the epiphysis in a 5-year old patient with a lytic lesion in distal femoral epiphysis that was confirmed by immunohistochemical methods. ${ }^{14}$ A similar case of ES/PNET of the proximal humeral epiphysis was reported in a 12-year-old patient which was confirmed by molecular testing was reported by Morris $\mathrm{P}$ et al in 2013. ${ }^{15}$ Most recently Heydar Ali et al in 2015 have reported a case of ES of proximal humeral epiphysis in a 13 year old patient. ${ }^{16}$ (Table 1$)$

\section{Table 1: Comparision of different studies on Ewing sarcoma at unusual locations}

\begin{tabular}{|c|c|c|c|c|c|}
\hline Study & Year & Age & Sex & Location & Radiological findings \\
\hline $\begin{array}{l}\text { Heydar A., } \\
\text { Mohammad T, } \\
\text { Shiva M. et al. }\end{array}$ & 2015 & 13years & Male & $\begin{array}{l}\text { Proximal humeral } \\
\text { epiphysis }\end{array}$ & A well defined lytic lesion \\
\hline $\begin{array}{l}\text { Reza A., } \\
\text { Mohammad M. }\end{array}$ & 2015 & 32 years & Male & $\begin{array}{l}\text { Tibial epiphysis } \\
\text { with retrobulbar } \\
\text { mass }\end{array}$ & $\begin{array}{l}\text { A minimal rarefaction in proximal } \\
\text { tibial epiphysis }\end{array}$ \\
\hline $\begin{array}{l}\text { Parisa M, Paul S, } \\
\text { Mathew J et al. }\end{array}$ & 2013 & 12 years & Male & $\begin{array}{c}\text { Proximal humeral } \\
\text { epiphysis }\end{array}$ & $\begin{array}{l}\text { A well defined lytic lesion with } \\
\text { surrounding edema }\end{array}$ \\
\hline $\begin{array}{l}\text { Ramanujam AS, } \\
\text { Anita C, Raman } \\
\text { SG }\end{array}$ & 2011 & 40years & Female & Shaft of radius & $\begin{array}{l}\text { A large destructive bony lesion with } \\
\text { adjacent soft tissue swelling }\end{array}$ \\
\hline Present study & 2017 & 15years & Male & Tibial epiphysis & $\begin{array}{l}\text { A large osteolytic lesion originating } \\
\text { from centre of tibial epiphysis } \\
\text { extending into metaphysis. }\end{array}$ \\
\hline
\end{tabular}

Historically, the differential diagnosis for pediatric epiphyseal lesions has included almost entirely benign lesions with the most common being chondroblastoma. ${ }^{17}$ Treatment for chondroblastoma is typically curettage and bone grafting, leading to complete healing and resolution. The treatment protocol for malignant bone tumors is radically different and must involve a multidisciplinary oncology team. The current case demonstrates importance of strict adherence to diagnostic strategies in dealing with bone lesions of unspecified nature. ${ }^{17,18}$
Histolologic classification of ES includes three major subtypes: Classic or conventional (typical) ES, primitive neuroectodermal tumor (PNET) and atypical ES. These tumors share the same immunohistochemical and molecular features differing only in the extent of neural differentiation. ${ }^{19}$

Classical ES is composed of small, round uniform cells with round nuclei and inconspicuous nucleoli.The nuclei have rather a smudgy appearance with indistinct cytoplasmic boundaries that seems to form a syncytium with embedded nuclei in it. Mitotic activity is usually not prominent in classic ES. ${ }^{20}$ 
PNET constitutes $10-15 \%$ of ES occurring in bone and soft tissue. The diagnosis requires the presence of Homer Wright rosettes with a central core of neuropil in a background of monotonous fields of conventional ES. $^{21}$

Atypical ES accounts for approximately $15 \%$ to $20 \%$ of genetically proven ES involving bone and soft tissue. This is the most difficult group to recognize because these tumors have a greater degree of cytologic variability and unusual growth patterns bringinig a broad variety of primary and metastatic small round cell tumors into differential diagnosis. Some tumors in this group contain large nuclei with irregular nuclear membranes and prominent nucleoli, whereas others have abundant eosinophilic cytoplasm imparting a rhabdoid appearance. In most cases tumor cells grow in sheets. However, less common morphologic patterns, including adamantinoma- like, vascular-like, spindle cell and sclerosing patterns. ${ }^{22}$

Immunohistochemistry plays a key role in confirming the diagnosis of ES. The most useful and sensitive marker is CD99/MIC-2. Upto 99\% of Ewing sarcomas express CD99 in a strong diffuse membranous pattern. ${ }^{17,18}$ Although it is a highly sensitive marker for this tumor, it is not specific. Various tumors containing small round cells may be immunoreactive with this marker including, lymphoblastic lymphoma, small cell osteosarcoma, mesenchymal chondrosarcoma, myeloid sarcoma and metastatic neuroendocrine tumors. FLI-1 is an another IHC marker expressed in around $75 \%$ of ES. ${ }^{23}$

ES is associated with a recurrent chromosomal translocation $\mathrm{t}(11 ; 22)(\mathrm{q} 24 ; 12)$, which results in formation of the fusion gene EWSR1-FLI1. This fusion gene occurs in more than $90 \%$ of cases and contains multiple splice variants. The two most common are type I and type II which together account for about $90 \%$ of EWSR1-FLI1 fusions. ${ }^{19}$

In this era, molecular studies (fluorescence in situ hybridization [FISH]) and molecular analysis (reverse transcriptase polymerase chain reaction [RT-PCR]) are the most accurate diagnostic modalities for confirming ES.22

ES has to be distinguished from osteosarcoma which is the most common primary bone tumour in children and adolescents. Osteosacrcoma occurs predominantly in metaphysis of long bones with characteristic microscopic feature of lace like pattern of malignant osteoid surrounding anaplastic tumor cells.

The other differential diagnoses of ES include osteomyelitis, chondroblastoma, giant cell tumor, clear cell chondrosarcoma, enchondroma and langerhans cell histiocytosis, lymphoma, leukemia and metastatic neuroblastoma. ${ }^{7}$ (Table 2)

Table 2: Comparative study of differential diagnoses of Ewing sarcoma

\begin{tabular}{|c|c|c|c|c|c|c|}
\hline Tumor & Age & Sex & Location & $\begin{array}{c}\text { Radiological } \\
\text { findings }\end{array}$ & $\begin{array}{c}\begin{array}{c}\text { Microscopic } \\
\text { features }\end{array} \\
\end{array}$ & $\begin{array}{c}\text { Immunohistochemis } \\
\text {-try findings }\end{array}$ \\
\hline $\begin{array}{l}\text { Small cell } \\
\text { osteosarcoma }\end{array}$ & $\begin{array}{c}\text { Biphasic, } \\
\text { young and } \\
\text { adolescents }\end{array}$ & $\mathrm{M}>\mathrm{F}$ & $\begin{array}{l}\text { Metaphysis of } \\
\text { long bones }\end{array}$ & $\begin{array}{l}\text { Codman's } \\
\text { triangle, } \\
\text { Periosteal } \\
\text { reaction }\end{array}$ & $\begin{array}{l}\text { Small cells with } \\
\text { malignant osteoid } \\
\text { formation }\end{array}$ & $\begin{array}{c}\text { CD } 99+, \text { osteocalcin } \\
+, \text { Osteopontin }+ \\
\text { Fli-1 -ve }\end{array}$ \\
\hline Chondroblastoma & $\begin{array}{c}\text { Second } \\
\text { decade of life }\end{array}$ & $\mathrm{M}>\mathrm{F}$ & $\begin{array}{l}\text { Most common } \\
\text { site is } \\
\text { epiphysis, } \\
\text { occasionally } \\
\text { metaphysis or } \\
\text { diaphysis }\end{array}$ & \begin{tabular}{|c|} 
A well \\
circumscribed \\
lesion with \\
sclerotic border
\end{tabular} & $\begin{array}{c}\text { Mixture of } \\
\text { mononuclear cells } \\
\text { and giant cells. } \\
\text { Mononuclear cells } \\
\text { with oval nuclei } \\
\text { and longitudinal } \\
\text { groove }\end{array}$ & $\begin{array}{c}\text { No specific markers. } \\
\text { S-100 }\end{array}$ \\
\hline $\begin{array}{l}\text { Mesenchymal } \\
\text { chondrosarcoma }\end{array}$ & $\begin{array}{l}\text { Adolescents, } \\
\text { children }\end{array}$ & $\mathrm{M}=\mathrm{F}$ & Jaw bones, ribs & $\begin{array}{l}\text { Non-specific } \\
\text { endosteal } \\
\text { scalloping, } \\
\text { cortical } \\
\text { thickening, } \\
\text { Periosteal } \\
\text { reaction }\end{array}$ & $\begin{array}{c}\text { Combination of } \\
\text { well differentiated } \\
\text { cartilage. Small } \\
\text { cells show } \\
\text { hyperchromatic } \\
\text { nuclei. }\end{array}$ & Sox 9+, Fli-1-ve \\
\hline Giant cell tumor & $\begin{array}{l}\text { Young adults. } \\
3^{\text {rd }} \& 4^{\text {th }} \\
\text { decade. }\end{array}$ & $\mathrm{F}>\mathrm{M}$ & $\begin{array}{l}\text { Metaphysis or } \\
\text { diaphysis of } \\
\text { long bones. }\end{array}$ & $\begin{array}{c}\text { Lytic } \\
\text { destructive } \\
\text { lesion }\end{array}$ & $\begin{array}{c}\text { Mononuclear } \\
\text { round to oval cells } \\
\text { with stromal cells } \\
\text { along with } \\
\text { osteoclast type of } \\
\text { giant cells. }\end{array}$ & p63+ \\
\hline $\begin{array}{l}\text { Primary } \\
\text { Lymphoma }\end{array}$ & Middle aged. & $\mathrm{M}>\mathrm{F}$ & $\begin{array}{l}\text { Metadiaphysis } \\
\text { of long bones }\end{array}$ & $\begin{array}{c}\text { Radiolucency } \\
\text { with } \\
\text { permeative } \\
\text { margins, } \\
\text { minimal onion }\end{array}$ & & $\begin{array}{c}\text { CD45, LCA,PAX 5, } \\
\text { Pan B \& T cell } \\
\text { markers, ALK+ }\end{array}$ \\
\hline
\end{tabular}




\begin{tabular}{|c|c|c|c|c|c|c|}
\hline & & & & $\begin{array}{l}\text { skin periosteal } \\
\text { reaction. }\end{array}$ & & \\
\hline Enchondroma & $10-40$ years & $\mathrm{M}=\mathrm{F}$ & $\begin{array}{l}\text { Small bones of } \\
\text { hand and feet }\end{array}$ & & $\begin{array}{c}\text { Lobulated, } \\
\text { hypercellular, } \\
\text { chondrocytes } \\
\text { arranged in } \\
\text { clusters with } \\
\text { abundant matrix }\end{array}$ & S-100 \\
\hline $\begin{array}{l}\text { Langerhans cell } \\
\text { histiocytosis }\end{array}$ & $\begin{array}{l}\text { Affects } \\
\text { patients all } \\
\text { ages, most } \\
\text { common in } \\
\text { children }\end{array}$ & $\mathrm{M}>\mathrm{F}$ & $\begin{array}{l}\text { Skull followed } \\
\text { by femur, } \\
\text { pelvis, rib. } \\
\text { Univocal } \\
\text { >Multifocal }\end{array}$ & $\begin{array}{l}\text { Radioluscent } \\
\text { lesion, } \\
\text { periosteal new } \\
\text { bone formation }\end{array}$ & $\begin{array}{c}\text { Oval nucleus } \\
\text { surrounded by } \\
\text { clear cytoplasm } \\
\text { with folded } \\
\text { nuclei/longitudinal } \\
\text { groove, mixed } \\
\text { inflammatory cell } \\
\text { infiltrate, plasma } \\
\text { cells, eosinophils, }\end{array}$ & $\begin{array}{c}\text { Langerin, CD1a,S- } \\
100\end{array}$ \\
\hline $\begin{array}{l}\text { Acute } \\
\text { Osteomyelitis }\end{array}$ & $\begin{array}{c}\text { Adolescents } \\
\text { under } 20 y r s \\
\text { age }\end{array}$ & $\mathrm{M}>\mathrm{F}$ & $\begin{array}{l}\text { Epiphysis \& } \\
\text { metaphysisof } \\
\text { long bones. }\end{array}$ & $\begin{array}{l}\text { Permeative } \\
\text { destructive } \\
\text { lesion }\end{array}$ & $\begin{array}{l}\text { Reactive new bone } \\
\text { formation, } \\
\text { capillary } \\
\text { proliferation with } \\
\text { acute } \\
\text { inflammatory } \\
\text { background }\end{array}$ & - \\
\hline
\end{tabular}

Our case highlights that although metadiaphyseal locations for ES are most common, epiphyseal location is also possible. This case adds to the limited but mounting evidence that ES should be considered in the differential diagnosis of pediatric epiphyseal tumors. The review of literature clearly suggests that only few cases of ES at epiphyseal location have been reported in past and this makes our case worth documenting.

\section{Conclusion}

ES at epiphyseal location is extremely rare and only few cases have been reported so far in literature. Our case highlights that the classical clinical and radiological presentation of ES of bone may not be a rule and one should be highly suspicious of the disease even if there is no feature of the disease as was encountered in our case. Orthopaedicians, radiologists and pathologists should be alert to this rare atypical occurrence of ES inorder to avoid chances of misdiagnosis.

\section{References}

1. Heck Jr RK. Malignant tumors of bone. In: Terry Canale S, Beaty JH. Campbell's operative orthopedics. $11^{\text {th }}$ ed. Philadelphia: Mosby;2008:901-38.

2. Greenspan A, Jundt G, Remagen W. Differential diagnosis in orthopedic oncology. $2^{\text {nd }}$ ed. Philadelphia: Lipincott Williams \& Wilkins;2007.

3. Nesbit ME Jr, Gehan EA, Burgert EO Jr, Vietti TJ, Cangir A, Tefft M, et al. Multiomodal therapy for the management of primary, non metastatic Ewing's sarcoma of bone : a long term follow-up of the First Intergroup study. J Clin Oncol.1990;8(10):1664-74.
4. Widhe B, Widhe T. Initial symptoms and features in osteosarcoma and Ewing sarcoma .J Bone Joint Surg Am.2000;82(5):667-74.

5. Kissane JM, Askin FB, Foulkes M, Stratton LB, Shirley SF. Ewing's sarcoma of bone. Clinicopathological aspect of 303 cases from the intergroup Ewing's sarcoma study. Hum Pathol.1983;14(9):773-9.

6. Mirra JM, Picci P, Gold RH. Bone tumors: clinical, radiologic, and pathologic correlations. Philadelphia: Lea \& Febiger;1989.

7. Hovy L. Epiphyseal tumors. Z Orthop Ihre Grenzgab.1996;134(5);413-417.

8. Green DM. Diagnosis and Management of Malignant Solid Tumors in infants and children. Boston MA: Martinus Nijhoff Publishing; 1985.

9. Wilkins RM, Pritchart DJ, Burgert Jr EO, et al. Ewing's sarcoma of bone: experience with 140 patients Cancer.1986;58(11);2551-2555.

10. Granowetter L, Womer R, Devidas M.et al. Dose intensified compared with standard chemotherapy for nonmetastatic Ewing sarcoma family of tumors: a Children's Oncology Group study. J clin Oncol.2009;27(15):2536-2541.

11. Reinus WR, Gilula LA.IESS committee: radiology of Ewing's sarcoma: intergroup Ewing's sarcoma study. Radiographics .1984;4:929-944.

12. 12.Lin PP, Thenappan A, Dreavers MT. Treatment and prognosis of chondroblastoma. Clin. Orthop Relat Res.2005;(438):103-109.

13. Moscolo DL, Campaner G, Aponte-Tinao LA, et al. Epiphyseal primary location for osteosarcoma and Ewing's sarcoma in patients with open physis. J Pediatr Orthop.2003;23(4):542-545.

14. Kowalezyk B, Lejman T, Drabik G, et al. Primary epiphyseal localization of primitive neuroectodermal tumor in a child. Eur J Radiol.2011;78:77-80.

15. Morris P, Dickman PS, Seidel MJ. Ewing's sarcoma/primitive neuroectodermal tumor of the proximal humeral epiphysis. Orthopedics $.2013 ; 36(1): 113-116$.

16. Heydar A, Mohammad T, Shiva M et al. Ewing's sarcoma of proximal humeral epiphysis. Archives of Iranian Medicine.2015;18:133-34. 
17. Bhansali SK, Desai PB. Ewing sarcoma: observation on 107 cases .J Bone Joint Surg Am.1963;45(3):541-53.

18. Friedman B, Hanoaka H. Round -cell sarcomas of bone. A light and electron microscopic study. J Bone Joint Surg Am.1971;53(6):1118-36.

19. Burchill SA. Ewing's sarcoma: diagnostic, prognostic and therapeutic implications of molecular abnormalities. J.Clin. Pathol. 2003;56(2):96-102.

20. 20.Maygarden SJ, Askin FB, Siegal GP, Gilula LA, Schoppe J, Foulkes M, et al. Ewing sarcoma of bone in infants and toddlers. A clinicopathological report from the Intergroup Ewing's Study. Cancer. 1993;2109-2118.

21. Moser RP, Davis MJ, Gilkey Moser RP, Davis MJ,

Gilkey FW, Kransdorf MJ, Rosado de Christenson ML, Kumar R, et al. Primary Ewing sarcoma of rib. Radiographics.1990;899-914.

22. Maheshwari AV, Cheng EY. Ewing sarcoma family of tumors. J Am Acad Orthop Surg. 2010;94-107.

23. Levine E, Levine C. Ewing tumor of rib: radiologic finding sand computed tomography contribution. Skeletal Radiol.1983;9(4):227-33. 